\title{
Morphology of COVID-19-affected cells in peripheral blood film
}

\author{
Aminder Singh, ${ }^{1}$ Neena Sood, ${ }^{1}$ Vikram Narang, ${ }^{1}$ Abhishek Goyal ${ }^{2}$
}

'Pathology, Dayanand Medical College and Hospital, Ludhiana, India

${ }^{2}$ Department of Cardiology, Dayanand Medical College and Hospital, Ludhiana, India

\section{Correspondence to} Dr Abhishek Goyal; drabhishekgoyal11@yahoo.in

Accepted 14 May 2020

\section{DESCRIPTION}

A 55-year-old previously healthy woman was admitted with fever and cough. Chest X-ray and CT showed features of viral pneumonitis. Her nasopharyngeal swab was positive for severe acute respiratory distress syndrome coronavirus-2 (SARS-CoV-2) by reverse transcription (RT)-PCR. Her complete blood count (CBC) showed leucocytosis with neutrophilia, relative lymphocytopaenia, and monocytopaenia initially with subsequent improvement in the number of monocytes on the fifth day onwards. We report a detailed analysis of the peripheral blood film (PBF) of a patient with COVID-19 during the hospital course which has not been reported hitherto. Some peculiar findings were observed in the neutrophils which were never seen in any other infection. Neutrophils showed heavily clumped chromatin with toxic granules and cytoplasmic vacuoles. Nuclear detachment with elongated nucleoplasm and ring-shaped nuclei were seen with platelet surface attachment. C-shaped, fetus-like nuclei were noted with aberrant nuclear projections, which we named as COVID nuclei (figure 1). Most of the lymphocytes were seen as large granular lymphocytes (LGL) with round to indented nuclei, condensed chromatin, prominent nucleoli in a few, along with abundant pale blue cytoplasm with distinct variably sized azurophilic

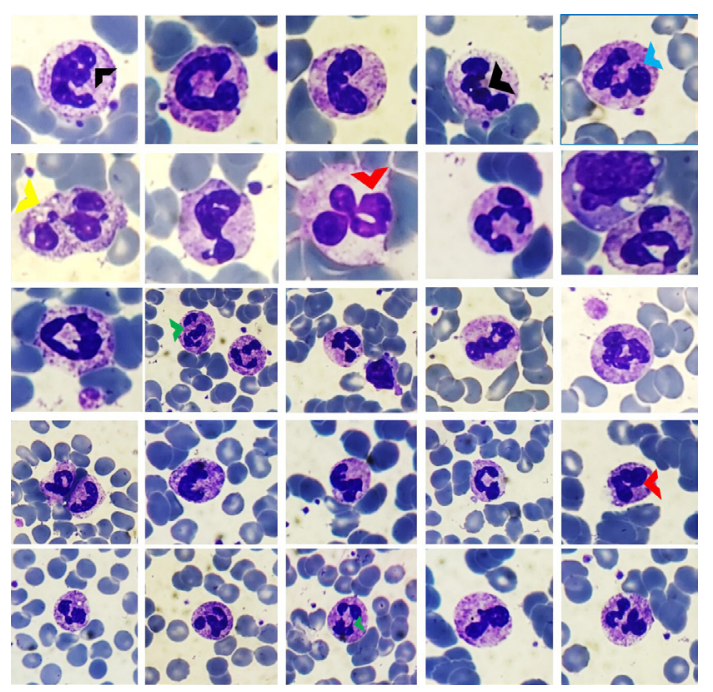

Figure 1 Peripheral blood films showing various neutrophils with C-shaped, fetus-like COVID nuclei (black arrowheads) with aberrant nuclear projections (blue arrowhead). Toxic granulations and vacuolations (yellow arrowhead), ring nuclei (red arrowheads) and elongated nucleoplasm (green arrowheads) are highlighted. Giemsa $\times 200-400$.

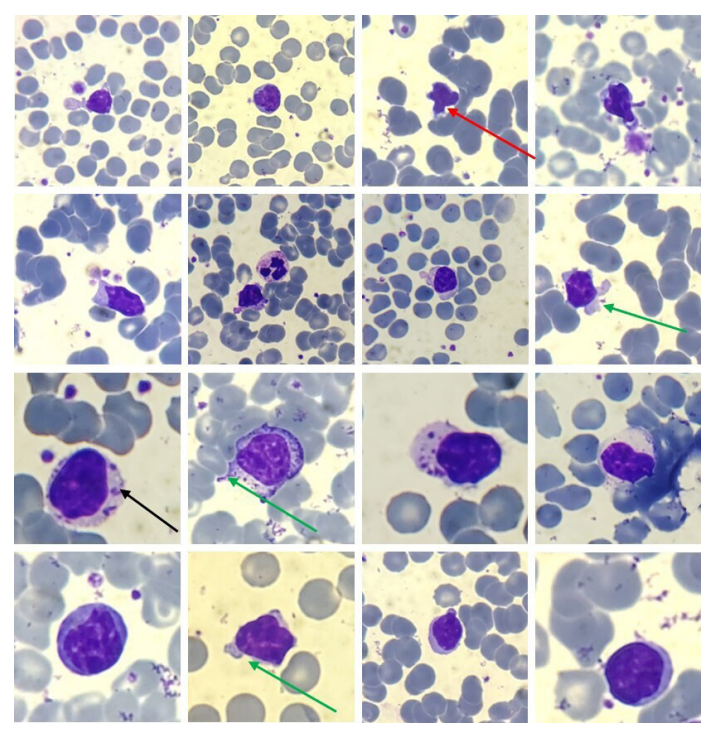

Figure 2 Peripheral blood films showing large granular lymphocytes. Round to indented nuclei, condensed chromatin, prominent nucleoli in a few, along with abundant pale blue cytoplasm with distinct variably sized azurophilic granules are present (long black arrow). Cytoplasmic pod formation (long green arrows) and apoptotic lymphocytes (long red arrow) are highlighted. Giemsa ×200-400.

granules (figure 2). Cytoplasmic pod formation and apoptosis were also observed in a few lymphocytes. These might represent natural killer cells or cytotoxic T lymphocytes. Activated monocytes were seen which showed marked anisocytosis with prominent cytoplasmic vacuolisation and few granules. Nuclei were large, having fine chromatin with nuclear blebbing in a few. Nuclear overlapping by vacuoles was observed in some cells (figure 3 ). Platelets were adequate, with a few giant forms and focal platelet attachment on the surface of

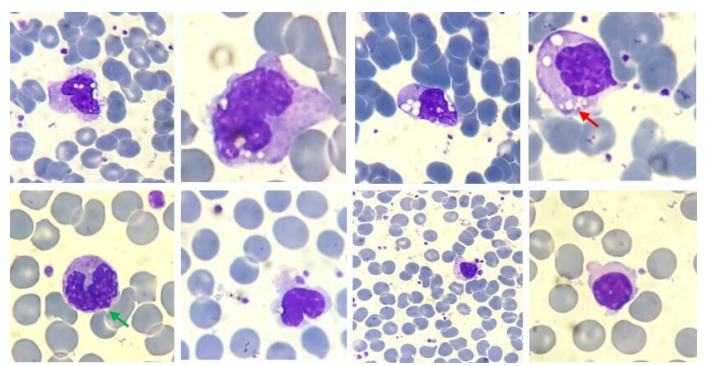

Figure 3 Peripheral blood films showing activated monocytes with prominent cytoplasmic vacuolisation and a few granules (small red arrow). Nuclear blebbing (small green arrow) is also seen. Giemsa $\times 200-400$. 
all forms of leucocytes. Her first CBC sample showed normal total leucocyte count $\left(7.4 \times 10^{9} / \mathrm{L}\right)$ with neutrophilia and relative lymphocytopaenia and monocytopaenia. On the fifth day onwards, her CBC started showing monocytosis, which persisted until day 16. Relative lymphocytopaenia persisted throughout her stay, along with the presence of LGL on PBF. LGL started appearing on PBF on day 7 onwards. These findings clearly indicated that in COVID-19, initial neutrophilia, lymphocytopaenia and monocytopaenia are subsequently accompanied by monocytosis. During the hospital stay, the patient was managed with oral hydroxychloroquine, azithromycin and antipyretics, along with intravenous fluids, bronchodilators and supportive care. The patient was discharged on 8 April 2020 after two negative samples for COVID-19.

COVID-19 is a highly contagious disease caused by SARS-CoV-2. It originated from the Chinese city of Wuhan and has reached the pandemic status in just a few months. It has now affected around 300 countries worldwide, causing significant morbidity and mortality. To date more than 254045 deaths have been reported. ${ }^{1}$

There are various challenges to the exact diagnosis of these patients. Clinically patients may be asymptomatic carriers. Sensitivity and specificity of currently available methods are very variable. $^{2}$

We have examined the PBF findings in a patient with COVID-19 which can help in the diagnosis and to some extent the prognosis of patients. The inflammatory response and viral effects on leucocytes might be responsible for these changes, which can be readily identified on PBF and can be easily and serially monitored. Monocytosis may be associated with favourable outcome, as seen in our patient. ${ }^{3}$

Understanding of the haematological manifestations of SARS-CoV-2 is still in the evolving stage. To reach a definite conclusion regarding the specificity and reliability of these viral cytopathic effects in peripheral smear, more patients positive for COVID-19 need to be evaluated in larger studies. Our goal is to describe the peculiar morphological findings of affected leucocytes, which would help physicians suspect a diagnosis in the absence of a negative RT-PCR or antibody results. If confirmed
Learning points

- In peripheral blood film (PBF), neutrophils showed characteristic C-shaped, fetus-like nuclei, elongated nucleoplasm, and ring-shaped nuclei.

- Large granular lymphocytes noted, a representation of natural killer cells or cytotoxic T lymphocytes.

- Activated monocytes indicated a favourable sign.

- COVID-19 viral effects on leucocytes are associated with characteristic changes that can be readily identified on PBF and can be easily and serially monitored, which could help in the diagnosis, prognostication and treatment protocols.

in larger studies, these morphological features along with blood count would be helpful in the screening, diagnosis and management of these patients at all levels of healthcare.

Contributors Conception and design: AS, NS, VN. Acquisition and analysis of data: $A S, A G$. Interpretation of data: $A S, A G, V N$. Drafting the article: $A S, A G, V N, N S$.

Funding The authors have not declared a specific grant for this research from any funding agency in the public, commercial or not-for-profit sectors.

Competing interests None declared.

Patient consent for publication Obtained.

Provenance and peer review Not commissioned; externally peer reviewed.

This article is made freely available for use in accordance with BMJ's website terms and conditions for the duration of the covid-19 pandemic or until otherwise determined by BMJ. You may use, download and print the article for any lawful, non-commercial purpose (including text and data mining) provided that all copyright notices and trade marks are retained.

\section{REFERENCES}

1 World Health Organization. Novel coronavirus (COVID-19) situation. Available: https:// covid19.who.int/

2 Cheng MP, Papenburg J, Desjardins M, et al. Diagnostic testing for severe acute respiratory Syndrome-Related Coronavirus-2: a narrative review. Ann Intern Med 2020:4:1-10.

3 Zhang D, Guo R, Lei L. COVID-19 infection induces readily detectable morphological and inflammation-related phenotypic changes in peripheral blood monocytes, the severity of which correlate with patient outcome. BioRxiv 2020.

Copyright 2020 BMJ Publishing Group. All rights reserved. For permission to reuse any of this content visit

https://www.bmj.com/company/products-services/rights-and-licensing/permissions/

BMJ Case Report Fellows may re-use this article for personal use and teaching without any further permission.

Become a Fellow of BMJ Case Reports today and you can:

- Submit as many cases as you like

- Enjoy fast sympathetic peer review and rapid publication of accepted articles

- Access all the published articles

Re-use any of the published material for personal use and teaching without further permission

Customer Service

If you have any further queries about your subscription, please contact our customer services team on +44 (0) 2071111105 or via email at support@bmj.com.

Visit casereports.bmj.com for more articles like this and to become a Fellow 